\title{
FILM SEBAGAI MEDIA DAKWAH ISLAM
}

\author{
Andi Fikra Pratiwi Arifuddin \\ Institut Agama Islam Negeri (IAIN) Manado, Indonesia \\ e-mail: iccipratiwi@gmail.com
}

\begin{abstract}
Abstrak. Dakwah merupakan kewajiban dan tanggung jawab umat Islam dalam menyebarkan ajaran-ajaran Islam sebagaimana termuat dalam al-Quran dan hadis yang bertujuan kepada 'amar makruf dan nahi mungkar'. Salah satu alternatif dakwah adalah melalui media film, dengan kemajuan teknologi di zaman sekarang pemanfaatan media tersebut dapat diefektifkan. Seiring dengan perkembangan perfilman Indonesia saat ini yang cenderung meningkatkan antusias para movie maker memproduksi karya-karya terbaiknya. Karya yang dihasilkan menjadi media dakwah dalam menyebarkan pesanpesan agama kepada masyarakat dengan mengemas kisah yang ringan, menghibur, cenderung mengangkat kisah yang dekat dengan keseharian masyarakat tanpa melupakan nilai motivasi yang terkandung dalam kaidah-kaidah Islam. Film merupakan manifestasi perkembangan kehidupan budaya masyarakat pada masanya. Konstruksi sebuah film misalnya, merupakan salah satu esensi menelevisikan kebudayaan tertentu, pada gilirannya merepresentasikan nilai-nilai budaya melalui demonstrasi skenario oleh sutradara-sineas.
\end{abstract}

Kata Kunci : Film, Media, Dakwah Islam

Abstract. Da'wah is an obligation and responsibilty of Moslem in spreading the teaching of Islam as stated in al Quran and Hadits toward the 'Amr ma'rufnahi munkar. An alternative for da'wah is through film. The advaced technology today benefits into this media effectiveness. Along with the recent development of Indonesian cinematography, movie makers enthusiastically produce their best creations. Those creations become da'wah media to spread the religion teachings to society through simple and entertaining stories that exploit topics closed to everyday events without omitting motivational values of Islam. The construction of a film, for example, is an essence of televisioning a certainculture which is in turn represents cultural values through scenarios created. One the film of this category is Dalam Mihrab Cinta.

Key words: Film, Media, Islamic Da'wah 


\section{A. Pendahuluan}

Di era agraris, peran ulama dan tokoh agama begitu kuat dalam mempengaruhi kehidupan masyarakat. Pendapat dan sikap mereka ditiru, didengarkan dan dilaksanakan. Bahkan, masyarakat rela berkorban dan mau datang ke tempat pengajian yang jaraknya jauh sekalipun, hanya karena cinta mereka kepada para ulama dan ingin mendapatkan taushyiah untuk dijadikan pedoman hidup yang baik dan benar. Dengan khusyu, tawadu dan memiliki semangat yang tinggi, mereka mendengarkan apa yang diucapkan ulama dan berupaya secara maksimal melaksanakan materi dakwah diperolehnya.

Kini masyarakat memasuki era modern, ulama dan pemerintah sekalipun tidak bisa merubah kekuatan tersebut. Modernisasi menurut Anthony Giddens merupakan sebuah keharusan yang tidak bisa ditolak kehadirannya. Modernisasi menjadi bagian dari perjalanan waktu dan ruangyang mesti terjadi. Konsekuensi logis dari perubahan tersebut, pola pikir, sikap, mental, dan perilaku umat, hendaknya dirubah mengikuti perkembangan zaman yang ada, termasuk menjalankan ajaran agama.

Perubahan masyarakat yang fenomenal tersebut, seharusnya diimbangi dengan adanya perubahan cara berdakwah yang dilakukan oleh para dai. Dakwah tidak boleh jalan di tempat dan menggunakan cara-cara konvensional saja (ceramah). Dakwah harus dinamis, progresif, dan penuh inovasi. Para dai perlu menciptakan kreasi-kreasi baru yang lebih membumi dan dapat membawa kemaslahatan umat. Dakwah perlu dikemas lebih manusiawi, dialogis, memenuhi kebutuhan dan kemampuan masyarakat.

Dunia hari ini sebenarnya menitipkan harapan besar terhadap dakwah Islam. Jika kaum muslimin menyadari kenyataan ini, lalu mereka semua mau bekerja, bersabar, dan serius dalam berdakwah Insya Allah dakwah Islam akan menjadi trend dunia di masa yang akan datang. ${ }^{1}$

Untuk mendukung adanya perubahan dalam berdakwah, para dai perlu terus menerus meningkatkan wawasan, ilmu yang dan kemampuan teknis yang diperlukan dalam melakukan dakwah. Dai tidak merasa puas dengan ilmu yang dimilikinya, melainkan terus belajar sepanjang hayat. Ilmu yang berkembang dewasa ini bersifat multidisipliner dan komplementer, ilmu agama yang selama ini menjadi pegangan dai (sumber utama) perlu diperkuat dengan keilmuan lainnya agar apa yang disampaikan ke masyarakat menjadi kokoh dan dapat dioperasionalkan kajian ilmu psikolog, sosiologi, sejarah dan sebagainya. Oleh karena itu, dai perlu memperkuat ilmu agama yang dimilikinya dengan menambah wawasan dan pengetahuan yang berdasar dari ilmu-ilmu sosial, humaniora maupun ilmu-ilmu alam.

Dengan memperluas pendekatan dalam mengembangkan ilmu Agama Islam, maka kegiatan, maka kegiatan dakwah pun bisa diperluas dengan berbagai pendekatan. Karena kegiatan dakwah diturunkan dari keilmuan dakwah yang notabene menjadi bagian dari keilmuan agama Islam. Kegiatan dakwah bisa didekati dengan ilmu manajemen, politik, sosiologi, antropologi, ilmu kesehatan dan sebaginya. Dengan cara demikian, kegiatan dakwah amat variatif. Kegiatan dakwah dapat mengakomodir berbagai kebutuhan yang berkembang di masyarakat.

Di awal millenium baru ini tampaknya mulai ada gairah baru dalam industri film Indonesia terutama film yang mengusung tema dakwah. Seperti halnya film Perempuan Berkalung Sorban, Ketika Cinta Bertasbih, film Ayat-ayat Cinta hingga Dalam Mihrab Cinta yang begitu

Hidayat Nurwahid, Pengantar Sejarah Dakwah, (Jakarta: Kencana, 2015), h. 238 
fenomenal semakin memberikan peluang bagi para penggiat sineas dakwah. Kenyataan kini tidak hanya film yang ber-genre-kan horor, percintaan remaja atau komedi yang bisa diterima masyarakat umum namun film yang bernuansakan Islam pun mampu menjadi tontonan dengan rating tinggi. Maka hal tersebut bisa menjadi suatu modal besar bagi para sineas dakwah dalam mengtransformasikan nilai keislaman pada media ini.

\section{B. Konsep dan Teori}

\section{Konsep Film}

a. Pengertian Film

Film² adalah gambara-hidup, juga sering disebut movie. Film sering disebut "sinema". Film dihasilkan dengan rekaman dari orang dan benda (termasuk fantasi dan figure palsu) dengan kamera. Film juga didefenisikan sebagau serentetan gambar yang bergerak dengan atau tanpa suara, baik yang terekam pada film, video tape, video disk, atau media lainnya. Sedangkan bahasa film adalah bahasa gambar.

Film menyampaikan ceritanya melalui serangkaian gambar yang bergerak, dari satu adegan ke adegan lainnya, dari satu emosi ke emosi lain, dari satu peristiwa ke peristiwa yang lain. Faktor utama dalam film adalah kemampuan gambar bercerita kepada publik penontonnya. Film pertama kali diciptakan pada tahun 1805 oleh Lumiere Brithers. Kemudian pada tahun 1899 George Melies mulai menampilkan film dengan gaya editing yang berjudul "Trip To The Moon". Pada tahun 1902 Edwin

Film adalah selaput, dipakai untuk menambah gulungan serangkaian gambar-gambar yang diambil dari obyek-obyek yang bergerak dan akhirnya proyeksi dari pada hasil pengambilan gambar tersebut., Ensiklopedi Indonesia (Jakarta; ichtiar baru, 1991), h. 1007.
Peter membuat film yang berjudul "Life of In American Fireman".

Kebutuhan manusia akan hiburan melalui sebuah gambar yang bergerak lama kelamaan mulai menarik minat masyarakat luas pada umumnya. Di sini mulai terletak adanya sebuah organize yang akan mengatur atau menyuplai film. Masuknya film sebagai dunia industri berawal organisasi perfileman. Sebuah karya film mulai diperjualbelikan atau dengan kata lain mulai ada value yang harus dikeluarkan oleh masyarakat, mulai ada peraturan-peraturan tentang segala hal yang berkaitan dengan film. ${ }^{3}$

\section{b. Unsur-Unsur Pembentukan Film}

Setiap membicarakan film, selalu bersinggungan dengan unsur-unsur pembentukan film. Pemahaman terhadap unsur-unsur pembentukan film tentu akan banyak membantu kita untuk memahami film dengan baik. Unsur-unsur pembentukan terdiri atas (1) unsur naratif dan unsur sinematik, dan (2) unsur naratif berhubungan dengan aspek cerita atau tema film. Kedua unsur tersebut diuraikan sebagai berikut. ${ }^{4}$

(1) Unsur naratif dan unsur sinematik. Dua unsur tersebut saling berinteraksi dan berkesinambungan satu sama lain untuk membentuk sebuah film. Masingmasing unsur tersebut tidak dapat membentuk film jika hanya berdirisendiri. Dapat dikatakan bahwa unsur naratif adalah bahan (materi) yang akan diolah, sementara unsur sinematik adalah cara (gaya mengolahnya). Dalam film cerita, unsur naratif adalah perlakuan terhadap cerita filmnya. Sementara unsur sinematik atau juga sering diistilahkan gaya sinematik merupakan

Indonext, “Tentang Film”, Situs Resmi Indonext. http://www. indonext27.blogspot.com/ (01 november 2017).

Ibid. 
aspek-aspek teknis pembentuk film seperti mise-en-scene, yaitu segala hal yang berada di depan kamera contohnya setting atau latar, tata cahaya, kostum, dan make up, serta akting dan pergerakan pemain.

(2) Unsur naratif berhubungan dengan aspek cerita atau tema film. Setiap film cerita tidak mungkin lepas dari unsur naratif. Setiap cerita pasti memiliki unsur-unsur seperti tokoh, masalah, konflik, lokasi, waktu, serta lainnya.

\section{c. Memahami Film}

Bahan baku atau materi yang menandai belum tentu menghasilkan sesuatu yang baik, jika seorang sutradara salah mengolahnya begitupun sebaliknya. Sebuah film yang memiliki cerita atau tema kuat bisa menjadi tidak berarti tanpa pencapaian sinematik dan naratif yang memadai. Bahasa film berupa kombinasi antara suara dan bahasa gambar merupakan media untuk memahami sebuah film secara mendalam. Sineas menawarkan sebuah solusi melalui filmnya dengan harapan tentunta bisa diterima dengan baik oleh orang yang menonton. Melalui pemahaman bahasa, pengalaman mental dan budaya yang dimilikinya, penonton berperan aktif secara sadar maupun tidak sadar untuk memahami sebuah film. Keberhasilan seseorang dalam memahami film secara utuh sangat dipengaruhi oleh pemahaman orang tersebut terhadap aspek naratif dan aspek simatik sebuah film. ${ }^{5}$

\section{d. Jenis-Jenis Film}

1) Film Dokumenter (Documentary Films) Film dokumenter menyajikan real kita melalui berbagai cara dan dibuat untuk berbagai macam tujuan. Namun harus diakui, film dokumenter tak pernah

Himawan Pratista., Memahami Film (Cet.1: Yogyakarta: Homerian Pustaka, 2008), h.3 lepas dari tujuan penyebaran informasi, dan pendidikan. Intinya, film dokumenter tetap berpijak pada hal-hal senyata mungkin. Seiring dengan perjalanan waktu, muncul berbagai aliran dari film dokumenter misalnya dokudrama (docudrama). Kini dokumenter menjadi sebuah tren tersendiri dalam perfilman dunia. Para pembuat film bisa bereksperimen dan belajar tentang banyak hal ketika terlibat dalam produksi film dokumenter. Ini bisa dilihat dari banyaknya film dokumenter yang bisa kita saksikan melalui saluran televisi seperti program National Geographic dan Animal Planet. Bahkan saluran televisi Discovery Channel pun mantap menetapkan diri sebagai saluran televisi yang hanya menayangkan program dokumenter tentang keragaman alam dan budaya.

2) Film Cerita Pendek (Short Films) Durasi film cerita pendek biasanya di bawah 60 menit. Di banyak negara seperti Jerman, Australia, Kanada, Amerika Serikat, dan juga Indonesia, film cerita pendek dijadikan laboratorium eksperimen dan batu loncatan bagi seseorang atau sekelompok orang untuk kemudian memproduksi film cerita panjang. Jenis film ini banyak dihasilkan oleh para mahasiswa jurusan film atau seseorang maupun kelompok yang menyukai dunia film dan ingin berlatih membuat film dengan baik. Sekalipun demikian, ada juga yang memang mengkhususkan diri untuk memproduksi film pendek, umumnya hasil produksi ini dipasok ke rumahrumah produksi atau saluran televisi. 
3) Film Cerita Panjang (Feature-Length Film)

Film dengan durasi lebih dari 60 menit pada umumnya berdurasi 90-100 menit. Film yang diputar di bioskop umumnya termasuk dalam kelompok ini. Beberapa film berdurasi lebih 120 menit. Film-film produksi India ratarata berdurasi hingga 180 menit.

\section{e. Klasifikasi Genre Film}

Istilah genre berasal dari bahasa Perancis yang bermakna "bentuk" atau "tipe". Dalam film genre dapat didefinisikan sebagai jenis atau klasifikasi dari sekelompok film yang memiliki karakter atau pola sama (khas) seperti setting, isi dan subyek, ikon, mood serta karakter. Klasifikasi tersebut menghasilkan genre-genre popular seperti aksi, petualangan, drama, komedi, horror, western, thriller, film noir, roman, dan sebagainya.

Fungsi utama genre adalah untuk memudahkan klasifikasi sebuah film. Film yang diproduksi sejak awal perkembangan sinema hingga kini mungkin telah jutaan lebih jumlahnya. Genre membantu kita memilih film-film tersebut sesuai dengan spesifikasinya. Selain itu klasifikasi, genre juga dapat berfungsi sebagai antisipasi penonton terhadap film yang akan ditonton. Jika seorang penonton telah memutuskan untuk melihat sebuah film bergenre tertentu maka sebelumnya ia telah mendapatkan gambaran umum (ide) di kepalanya tentang film yang akan ia tonton.

Gambaran umum sebuah film yang ditonton terdiri atas (1) elemen pokok narasi, (2) pelaku cerita, (3) permasalahan dan konflik, (4) tujuan, dan (5) jenis-jenis pemain. Kelima hal tersebut diuraikan sebagai berikut.
(1) Elemen Pokok Narasi. Dalam setiap film cerita pasti memiliki naratif yang berbeda-beda. Jika ada kemiripan cerita sekalipun pasti terdapat perbedaan dalam rincian cerita, pelaku, lokasi, masalah, konflik, resolusi, dan sebagainya. Pada dasarnya dalam tiap cerita film di samping aspek ruang dan waktu juga memiliki elemen-elemen pokok yang sama, yakni berkarakter, permasalahan atau konflik, serta tujuan. Dapat kita simpulkan bahwa inti cerita dari semua film (fiksi) adalah bagaimana seorang karakter menghadapi segala masalah untuk mencapai tujuan karakter pasti menghadapi masalah atau sebaliknya masalah yang mampu memotivasi tujuan. Bila tidak ada masalah, alur cerita tidak mungkin akan berkembang. Tanpa masalah-masalah tersebut cerita filmnya tidak akan pernah berjalan.

(2) Pelaku cerita. Setiap film cerita umumnya memiliki karakter utama dan pendukung. Karakter utama adalah motivator utama yang menjalankan alur naratif sejak awal hingga akhir cerita. Tokoh utama sering diistilahkan pihak protagonis sedangkan karakter pendukung bisa berada pada pihak protagoni maupun pihak antagonis (musuh atau rival). Karakter pendukung sering bertindak sebagai pemicu konflik (masalah) atau kadang sebaliknya dapat membantu karakter utama dalam menyelesaikan masalah.

(3) Permasalahan dan konflik. Permasalahan dapat diartikan sebagai penghalang yang dihadapi tokoh protagonis untuk mencapai tujuannya. Permasalahan seringkali ditimbulkan pihak 
antagonis karena memiliki tujuan yang sama atau berlawanan dengan pihak protagonis. Permasalahan klasik antara karakter protagonis dan antagonis adalah satu pihak ingin menguasai dunia sementara pihak lainnya ingin menyelamatkan dunia. Permasalahan ini pula yang memicu konflik (kontroversi) fisik antara pihak protagonis dan antagonis. Masalah dapat muncul dari dalam diri tokoh utama sendiri yang akhirnya memicu konflik batin.

(4) Tujuan. Setiap pelaku (utama) dalam semua film cerita pasti memiliki tujuan, harapan atau cita-cita. Tujuan dan harapan tersebut dapat bersifat fisik (materi) maupun non-fisik (nonmateri). Tujuan fisik sifatnya jelas dan nyata sementara non-fisik sifatnya tidak nyata (abstrak). Film-film super hero umumnya bertujuan jelas, yakni mengalahkan musuhnya untuk menyelamatkan umat manusia; film roman bertujuan mendapatkan sosok pujaan hatinya; film kriminal bertujuan mengungkap kasus dan menangkap pelaku kejahatan. Adapun film-film drama dan melodrama sering kali bertujuan nonfisik seperti mencari kebahagiaan, kepuasan batin, eksistensi diri dan sebagainya. ${ }^{6}$

(5) Jenis-jenis pemain. Secara umum para pemain dalam sebuah film dapat dikelompokkan menjadi beberapa jenis, yakni:

(a) Figuran, dalam sebuah film adalah semua karakter di luar para pelaku cerita utama. Pemain figuran sering digunakan untuk adegan-adegan yang bersifat masal, seperti perang

Ibid., h. 43-44 serta aksi-aksi di ruang publik yang ramai.

(b) Aktor amatir, biasanya digunakan bukan karena kemampuan akting mereka namun karena otentitas mereka dan karakter yang diperankan.

(c) Aktor profesional, adalah seorang yang sangat terlatih dan mampu bermain dalam segala jenis peran yang diberikan pada mereka dengan berbagai macam gaya.

(d) Bintang, seorang bintang dipilih karena nama besar mereka di mata publik. Penggunaan seorang bintang dalam sebuah film biasanya menjadi kunci sukses sebuah film.

(e) Superstar, adalah seorang yang sangat popular. Film-film yang dibintangi superstar selalu sukses luar biasa secara komersil.

(f) Chameo, adalah penampil sesaat seorang bintang ternama atau seseorang yang popular di mata publik.

\section{Media Dakwah}

Dakwah merupakan kewajiban dan tanggung jawab umat Islam dalam menyebarkan ajaran-ajaran Islam sebagaimana termuat dalam al-Quran dan Hadits ${ }^{7}$ yang bertujuan untuk mewujudkan amar makruf wa nahi mungkar. Dalam dakwah terdapat ide tentang progresivitas, yakni sebuah proses terus menerus menuju kepada yang baik dan yang lebih baik dalam mewujudkan tujuan dakwah itu sehingga dalam dakwah ada ide dinamis;

Kustadi Suhadang., Ilmu Dakwah Perspektif Komunikasi (Bandung; Rosda, 2013), h. 11-12 
sesuatu yang terus tumbuh dan berkembang sesuai dengan tuntutan ruang dan waktu. ${ }^{8}$

Salah satu alternatif dakwah yang cukup efektif adalah melalui media film, karena dengan kemajuan teknologi di zaman sekarang pemanfaatan media tersebut cukup efektif, seiring dengan perkembangan perfilman Indonesia saat ini yang cenderung meningkatkan antusias para movie maker memproduksi karya terbaiknya. Karya yang dihasilkan menjadi media dakwah cukup efektif dalam menyebarkan pesan-pesan agama kepada masyarakat dengan mengemas kisah yang ringan, menghibur, cenderung mengangkat kisah yang dekat dengan keseharian masyarakat tanpa melupakan nilai motivasi yang terkandung dalam kaidah-kaidah Islam.

Ghazali M. Bahri dalam bukunya "Dakwah Komunikatif" menjelaskan ada beberapa jenis media komunikasi yang dapat digunakan dalam kegiatan dakwah:

(a) Media visual merupakan alat komunikasi yang dapat digunakan dengan memanfaatkan indera penglihatan dalam menangkap data. Seperti film slide, OHP, gambar foto diam, computer.

(b) Media auditif dalam pemahaman komunikatif merupakan alat komunikasi yang berbentuk hasil teknologi canggih dalam wujud hardware, media auditif dapat di tangkap melalui indera pendengaran. Seperti radio, tape recorder, telepon dan telegram.

(c) Media audio visual merupakan perangkat komunikasi yang dapat ditangkap baik melalui indera pendengaran maupun penglihatan. Seperti movie film, televisi, video, media cetak. Apabila dibandingkan dengan media yang telah dikemukakan sebelumnya,

Aep kusnawan, Ilmu Dakwah (Bandung; Pustaka Bani Quraisy), h. 30 ternyata media audio visual lebih sempurna. Sebab media ini dapat dimanfaatkan oleh semua kalangan masyarakat.

\section{Teori Semiotika}

Semiotika adalah suatu ilmu metode analisis untuk mengkaji tanda. Tanda-tanda adalah perangkat yang kita pakai dalam upaya berusaha mencari jalan di dunia ini, di tengahtengah manusia dan bersma-sama manusia. Adapun teori semiotika yang digunakan adalah Ferdinand de Saussure.

Ferdinand de Saussure disebut sebagai pendiri linguistic modern. Saussure adalah sarjana dan tokoh besar yang berasal dari swiss. Saussre memang terkenal karena teorinya tentang tanda. Ia sebetulnya tidak pernah mencetak pemikirannya menjadi buku. Catatancatatannya dikumpulkan muridnya menjadi sebuah outline. Menurut Saussure, tanda terdiri atas (signifier) bunyi-bunyian dan gambar, (signified) konsep-konsep dari bunyi-bunyian dan gambar. Tanda (sign) adalah didengar yang biasanya merujuk kepada sebuah obyek aspek dari realitas yang ingin dikomunikasikan. Objek tersebut dikenal dengan "refrent". Dalam berkomunikasi seseorang menggunakan tanda untuk mengirim makna tentang objek dan orang lain akan menginterpretasikan tanda tersebut. Contoh, ketika orang menyebutkan kata "anjing" (signifier) dengan nada mengumpat maka hal tersebut merupakan tanda kesialan (signified). Begitulah, menurut Saussure, signifier dan signified merupakan kesatuan, tak dapat dipisahkan. ${ }^{9}$

Ada beberapa pandangan yang menjelaskan mengenai teori atau konsep makna. Model proses makna Wendell Jhonson menawarkan sejumlah implikasi bagi komunikasi antarmanusia:

Ibid., h. 268 
(a) Makna ada dalam diri sendiri. Makna tidak terletak pada kata-kata melainkan pada manusia. Kita menggunakan katakata untuk mendekati makna yang ingin kita komunikasikan. Namun katakata ini tidak secara sempurna dan lengkap menggambarkan makna yang kita maksud.

(b) Makna berubah. Kata-kata relatif statis, namun makna dari kata-kata ini terus berubah, dan ini khususnya terjadi pada makna dimensi emosional dari makna.

(c) Makna membutuhkan acuan. Walaupun tidak semua komunikasi mengacu pada dunia nyata, komunikasi hanya masuk akal bilamana ia mempunyai kaitan dengan dunia atau lingkungan eksternal.

(d) Penyingkatan yang berlebihan akan mengubah makna. Makna membutuhkan acuan adalah masalah komunikasi yang timbul akibat penyingkatan berlebihan tanpa mengaitkannya dengan acuan yang konkret dan dapat diamati.

(e) Makna tidak terbatas jumlahnya. Jumlah kata dapat terbatas pada suatu saat tertentu, tapi tetap memiliki makna yang luas. Hal ini dapat menimbulkan interpretasi yang berbeda kesepakatan supaya akan hilang.

(f) Makna dikomunikasin hanya sebagian. Makna yang kita peroleh dari suatu kejadian bersifat multi aspek dan sangat kompleks, tetapi hanya sebagian saja dari makna-makna ini yang benarbenar dapat dijelaskan.

\section{Pembahasan}

\section{Pembagian Media Dakwah}

Pada dasarnya, komunikasi dakwah dapat menggunakan berbagai media yang dapat merangsang indra-indra manusia serta dapat menimbulkan perhatian untuk dapat menerima dakwah. Berdasarkan banyaknya komunikan yang menjadi sasaran dakwah, diklasifikasikan menjadi dua, yaitu media massa dan nonmassa. $^{10}$

\section{a. Media massa}

Media massa digunakan dalam komunikasi apabila komunikan berjumlah banyak dan bertempat tinggal jauh. Media massa yang banyak digunakan dalam kehidupan seharihari umumnya surat kabar, radio, televisi, dan film bioskop yang beroperasi dalam bidang informasi dakwah.

Keuntungan dakwah dengan menggunakan media massa adalah bahwa media massa menimbulkan keserempakan artinya suatu pesan dapat diterima oleh komunikan yang jumlahnya relatif banyak. Jadi untuk menyebarkan informasi media massa sangat efektif dalam mengubah sikap, perilaku, pendapat komunikan dalam jumlah yang banyak.

b. Media non-massa

Media ini biasanya digunakan dalam komunikasi untuk orang tertentu atau kelompokkelompok tertentu seperti surat, telepon, sms, telegram, faks, papan pengumuman, CD, e-mail, dan lain-lain semua itu dikategorikan karena tidak mengandung nilai keserempakan dan komunikannya tidak bersifat massal. Secara terperinci Hamzah Ya'qub membagi media dakwah itu menjadi lima:

Wahyu Ilahi, Komunikasi Dakwah, (Bandung: Remaja Rosdakarya, 2010), h. 105 
1) Lisan, inilah media dakwah yang paling sederhana yang menggunakan suara. Media ini dapat berbentuk pidato, ceramah, kuliah, bimbingan, penyuluhan, dan lain sebagainya.

2) Tulisan, majalah, surat kabar, korespondensi (surat, e-mail, sms), spanduk dan lain-lain.

3) Lukisan, gambar, karikatur, dan sebagainya.

4) Audio visual, yaitu alat dakwah yang merangsang indera pendengaran atau penglihatan dan kedua-duanya. Bisa berbentuk televisi, slide, internet, dan sebagainya.

5) Akhlak, yaitu perbuatan-perbuatan nyata yang mencerminkan ajaran Islam yang dapat dinikmati dan didengarkan oleh mad'u.

\section{Film Bergenre Religi}

Film merupakan manifestasi perkembangan kehidupan budaya masyarakat pada masanya. Dari zaman ke zaman, film mengalami perkembangan baik dari segi teknologi yang digunakan maupun tema yang diangkat. Hal ini disebabkan film berkembang sejalan dengan unsur-unsur budaya masyarakat yang melatarbelakanginya. Semua makna budaya diciptakan dengan menggunakan simbol-simbol. Makna hanya dapat disimpan di dalam simbol. ${ }^{11}$ Budaya dapat dipahami sebagai tatanan kehidupan yang di dalamnya manusia membangun makna melalui praktik-praktik reperesentasi simbolik yakni dengan berkomunikasi satu sama lain. ${ }^{12}$

Di dalam berkomunikasi, sebenarnya terdapat berbagai simbol yang sering dijumpai dan sarat dengan makna yang signifikan dengan budaya. Salah satu contoh yang diketengahkan

\footnotetext{
1 Alex Sobur., Semiotika Komunikasi, (Cet.3; Bandung; Remaja Rosdakarya, 2006), h.176-177

12 Idi Subandy., Budaya Popular Sebagai Komunikasi, (Cet.1; Jogiakarta; Jalasutra, 2007), h. xx-xxi
}

adalah produksi budaya televisi, membudayakan televisi berarti menjadikan televisi bagian yang fungsional dari perkembangan kebudayaan. ${ }^{13}$ Konstruksi sebuah film misalnya, merupakan salah satu esensi menayangkan kebudayaan tertentu, pada gilirannya merepresentasikan nilai-nilai budaya melalui demonstrasi skenario oleh sutradara-sineas.

Kekuatan sebuah agama dalam menyangga nilai-nilai sosial, terletak pada kemampuan simbol-simbolnya untuk merumuskan sebuah dunia tempat nilai-nilai itu menjadi bahan dasarnya. ${ }^{14}$ Kerena itu, film bergenre religius di Indonesia cenderung dapat dimaknai sebagai repsresentasi suatu budaya religi yang dihadirkan melalui teknologi visualisasi simbol-simbol yang signifikan dengan realitas sosial.

Realitas sosial budaya teridentifikasi melalui simbol, bagaimana manusia berkomunikasi lewat simbol. ${ }^{15}$ Komunikasi terjadi dengan perantaraan tanda-tanda (sign), basis seluruh komunikasi adalah tanda-tanda. ${ }^{16}$ Dari sudut pandang itu, relatif mendukung eksistensi simbolis yang tersaji dalam film bergenre religius. Di mana unsur-unsur simbolis (tanda) religius suatu film, secara struktural dapat diidentifikasi dalam tema, narasi-bahasa, karakter penokohan, busana yang digunakan, dan lainnya sebagai mencerminkan nilai-nilai keagamaan.

\section{Kelebihan dan Kekurangan Film sebagai Media Dakwah}

Kelebihan Film sebagai media dakwah ini antara lain:

a. Secara Psikologis, penyuguhan secara hidup dan nampak yang dapat berlanjut dengan animation mempunyai kecenderungan umum yang unik dalam ke-

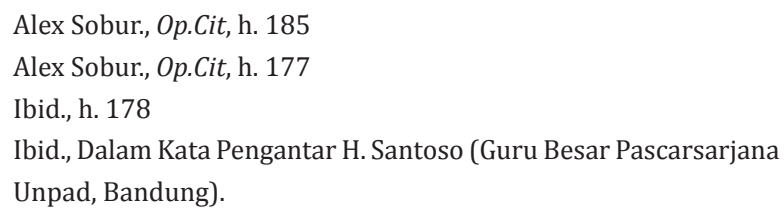


unggulan daya efektivitasnya terhadap penonton. Banyak hal-hal yang abstrak dan samar-samar serta sulit diterangkan, dapat disuguhkan pada khalayak secara lebih baik dan efisien oleh media film ini.

b. Bahwa media film yang menyuguhkan pesan yang hidup akan mengurangi keraguan apa yang disuguhkan, lebih mudah diingat dan mengurangi kelupaan.

c. Khusus bagi khalayak anak-anak dan sementara kalangan orang dewasa cenderung menerima secara bulat, tanpa lebih banyak mengajukan pertanyaan terhadap seluruh kenyataan situasi yang disuguhkan film. ${ }^{17}$

Film juga dapat mempengaruhi emosi penonton ini memang sangat mengesankan, seperti film tentang Risalah Muhammad "THE MESSAGE", film Sejarah Wali Songo, dan sebagainya yang pernah ditayangkan di tengah-tengah masyarakat dapat seolah-olah menghidupkan kembali kenangan sejarah Islam yang ada. Di samping itu, dalam perkembangan sekarang pengajaran salat, menasik haji, dan ibadahibadah praktis lainnya dapat dengan mudah diajarkan melalui video dan sebagainya. Akan tetapi yang perlu diingat bahwa dakwah melalui media ini memerlukan biaya yang cukup mahal.

Pakar komunikasi Rogers \& Shoemaker menyatakan bahwa komunikasi adalah proses pesan yang disampaikan dari sumber kepada penerima. Komunikasi yang menyebar melalui media massa akan memiliki dampak vertikal (mengalami taraf internalisasi/penghayatan) apalagi jika para tokoh (opinion-leaders) ikut menyebarkannya. Sementara pakar komunikasi lain, Lazarfield menyatakan bahwa jalannya

17 Hasan Bisri WD, , Ilmu Dakwah, (Surabaya: Biro Penerbitan dan Pengembangan Ilmiah, 1998), h. 45 pesan melalui media massa akan sangat mempengaruhi masyarakat penerimanya.

Dakwah melalui film lebih komunikatif sebab materi dakwah diproyeksikan dalam suatu skenario yang memikat dan menyentuh keberadaan masyarakat dalam kehidupan sehari-hari ${ }^{18}$. Sehingga mampu memberikan nilainilai ajaran moral Islam yang sesuai dengan kebutuhan madunya.

\section{Film "Dalam Mihrab Cinta" sebagai Media Dakwah}

Salah satu karya novelis yang diangkat ke layar lebar yakni Habiburrahman El Shirazy. Film yang disutradarai oleh Habiburrahman relatif memberikan gambaran realitas religius melalui media film. Namun, struktur film bertema religi tersebut, perlu ditelaah secara substansial apakah pesan simbolik dalam film itu merupakan representasi makna religi suatu agama, bukan justru pembiasan atau reduksi nilai agama. Dalam pada itu, khususnya ajaran Islam menyeru kepada umat Muslim agar cermat memilih dan memilah sajian informasi.

Salah satu film religi yang menjadi fenomena dan cenderung menarik perhatian sebagian khalayak, adalah film Ayat-Ayat Cinta. Film ini merupakan film religi hasil adaptasi dari sebuah novel best seller karya Habiburrahman El Shirazy berjudul Ayat Ayat Cinta yang ditulisnya dalam keadaan kaki kanannya patah.19 Ide cerita (film) terinspirasi dari al-Quran surat Az Zukhruf ayat 67, yang artinya "Orang-orang yang suka saling mencintai satu sama pada hari kiamat akan bermusuhan kecuali orang-orang yang bertakwa".20

18 Dr. Ghazali M. Bahri, M.A, Dakwah Komunikatif "Membangun Kerangka Dasar Ilmu Komunikasi Dakwah' (Jakarta; CV Pedoman Ilmu Jaya, 1997), h. 33-34

19 Habiburrahman El Shirazy., "Habiburrahman El Shirazy Ustadz 'Luar-Dalam' di KCB, Khalifah, Edisi 26 (September 2010), h. 43

2 Departemen Agama R.I., Al-Quran dan Terjemahannya (Semarang; CV. Toha Putera, 1989), h. 803. Terjemahan aslinya "Teman-teman 


\section{(1) Synopsis film "Dalam Mihrab Cinta"}

Film Dalam Mihrab Cinta menceritakan Syamsul (Dude Harlino) adalah seorang pemuda berusia 20 tahunan bertekad menuntut ilmu di sebuah pesantren di Kediri, meninggalkan kehidupannya yang cukup nyaman. Di sini, ia bertemu dengan Zizi (Meyda Sefira) putri pemilik pesantren yang pernah ditolongnya ketika dijambret di kereta api, sehingga kejadian tersebut membuat mereka jadi dekat. Di pesantren ini, Syamsul terusir karena dituduh mencuri akibat fitnah sahabatnya sendiri, Burhan (Boy Hamzah). Kemudian karena keluarganya sendiri juga tidak mempercayainya, hingga benar-benar membuat Syamsul menjadi seorang pencopet. Beberapa saat menjalani kehidupan sebagai seorang pencopet, Syamsul mengalami tekanan batin hingga membuatnya tersadar akan perbuatannya yang tidak terpuji. Syamsul pun bertobat dan memulai kehidupannya yang baru dengan melamar pekerjaan ke beberapa tempat. Pada titik inilah permulaan perubahan karakter Syamsul dari seorang pencopet menjadi seorang guru mengaji yang disegani.

Syamsul yang awalnya menyamar sebagai guru mengaji demi menyelamatkan Silvi dari kejahatan Burhan, belakangan justru menikmati perannya. Si pencopet itu kemudian terkenal menjadi ustaz muda yang ceramah-ceramahnya mampu membius pendengarnya. Alur kehidupnnya pun seketika berubah. Sang pencopet berubah laksana malaikat yang tanpa cela. Seperti film-film sebelumnya, film ini juga diwarnai pergulatan batin Syamsul yang bingung memilih siapa perempuan yang akan mendampingi hidupnya.

akrab pada hari itu sebagainya menjadi musuh bagi sebagian yang lain kecuali orang-orang bertakwa".
Film karya Habiburrahman El Shirazy (sebagai penulis serta yang menyutradarai filmnya sendiri), suatu hal yang memungkinkan dan yang ingin ditonjolkan adalah pesan nilai-nilai Islam dalam filmnya. Namun, pada waktu dan tempat yang berlainan, masyarakat dengan varian latar belakang budaya, pendidikan, dan seterusnya, bahkan dalam pengakajian mendalam (riset ilmiah) para analis kata "cinta" dibelakang kata "mihrab", yang boleh jadi memberi makna sosial multi interpretasi yang cenderung tidak relevan dengan nuansa religi. Berbeda halnya dengan analisa konteks sosial budaya, di mana Habiburrahman pada scene tertentu menggambarkan simbol atau ciri khas budaya Jawa di dalam filmnya. Misalnya, dari segi bahasa (kejawen) dan dialeknya, dari segi pakaian (batik), dan lain sebagainya yang menampilkan budaya Jawa secara simbolis.

\section{(2) Analisis Film "Dalam Mihrab Cinta"}

Film "Dalam Mihrab Cinta” tersusun atas tanda, penanda, petanda, dan referen yang mengkonstruksi tiap adegan-adegan yang memiliki makna untuk diartikan oleh para penonton. Tiap makna yang tersaji pada film tersebut dapat diinterpretasikan secara bebas oleh penikmatnya. adapun pengertian tanda, penanda, petanda, dan eksternal menurut Ferdinand de Saussure:

1. Tanda: terdir dari bunyi-bunyian dan gambar.

2. Penanda: dapat dilihat sebagai bentuk atau wujud fisik dapat dikenal melalui karya arsitektur.

3. Petanda: dapat dilihat sebagai makna yang terungkap melalui konsep, fungsi dan atau nilai-nilai yang terkandung di dalam karya arsitektur. 
4. Referen: Saussure memaknai "objek" sebagai referen dan menyebutkannya sebagi unsur tambahan dalam proses penandaan. Contoh: ketika orang menyebut kata "kucing hitam" (signifier) dengan nada takut maka hal tersebut merupakan tanda kurang baik (signified).

Tanda adalah kesatuan dari bentuk penanda dengan sebuah ide atau petanda. Dengan kata lain, penanda adalah "bunyi yang bermakna" atau "coretan yang bermakna". Maka, penanda adalah aspek material dari bahasa: apa yang dikatakan atau didengar dan apa yang ditulis atau dibaca. Sedangkan petanda adalah gambaran mental, pikiran atau konsep.

\section{a. Struktur tanda film "Dalam Mihrab Cinta"}

Komunikasi pada dasarnya merupakan tindakan yang dilakukan dengan menggunakan lambang-lambang. Lambang yang paling umum digunakan dalam komunikasi antarmanusia atau bahasa verbal dalam bentuk kata-kata, kalimat-kalimat, angkaangka atau tanda-tanda lainnya.

Bahasa verbal yang digunakan untuk keperluan yang tentunya akan berbeda tidak hanya menyangkut kata-kata yang digunakan tetapi nada atau intonasinya ${ }^{21}$. Pada film "Dalam Mihrab Cinta" mengandung unsur tanda verbal sebagai berikut:

a. Tanda Verbal :

1) Tanda dari segi busana, yaitu kopiah, baju kokoh, baju batik, busana muslimah, topi kupluk, kaca mata hitam, selendang (digunakan oleh para kiai).

21 Sattu Alang, Muh. Anwar, dan Hakkar Jaya, Pengantar ilmu Komunikasi (Makassar: Alauddin Press, 2007), h.13.
2) Tanda dalam struktur bahasa religi, misalnya kalimat Insya Allah, Astagfirullah, Alhamdulillah, Subhanalla.

3) Tanda dalam struktur bahsa budaya, misalnya dialek Jawa, seperti nggeh (iya) sopojennengmu? (siapa namamu), masih sugeng (dalam keadaan sehat), dan lain sebagainya. Selain bahasa verbal juga ada lambanglambang yang non-verbal yang dapat digunakan dalam komunikasi seperti gesture tubuh (gerak tangan, kaki atau bagian lainnya dari tubuh), warna sikap duduk atau berdiri, jarak, dan berbagai bentuk lambang lainnya. Penggunaan lambang-lambang non-verbal ini lazimnya dimaksudkan untuk memperkuat arti pesan yang disampaikan. Pada film "Dalam Mihrab Cinta” mengandung unsur non verbal, sebagai berikut:

b. Tanda non-verbal

1) Saling menganggukkan kepala, dan tersenyum menandakan tanda salam atau menyapa oleh Burhan pada Syamsul.

2) Syamsul memegang bagian perutnya sambil tersungkur di lantai menandakan Syamsul menahan sakit akibat pukulan dari santri.

3) Mengangkat tangan kanan ke atas dilakukan Syamsul sebagai tanda ia bersumpah. Dan lain sebaginya.

Selain tanda verbal dan non-verbal, terdapat struktur-struktur film yang menjadi bagian penting dalam sebuah karya film "Dalam Mihrab Cinta", di antaranya:

1) Penunjuk status sosial para pelaku ceritanya. Setting untuk kalangan atas terkesan di perumahan mewah, terlihat pada keluarga Silvie 
dan Burhan. Kalangan sederhana identik dengan properti yang secukupnya, dengan ruang yang tidak terlalu besar, terlihat pada keluarga Syamsul dan Zizi.

2) Sound. Ilustrasi musik adalah musik latar yang mengiringi aksi selama cerita berjalan. Sering berupa musik tema, yang membentuk dan memperkuat mood cerita, serta utama filmnya. Pada film ini mayoritas menggunakan instrumen musik. Instrument satu dan instrumen lainnya memiliki karakter yang berbeda pula. Masing-masing instrumen mampu membentuk sebuah mood. Penggunaan instrumen musik yang bertempo cepat atau keras mampu memberikan mood yang energik atau situasi yang tegang. Sedangkan instrumen dengan tempo yang lembut atau lambat menghasilkan mood yang tenang atau suasana yang mengharukan.

3) Lagu. Lagu tema bersama liriknya digunakan untuk mendukung mood adegannya, seperti sedih, bahagia, mencekam, dan sebagainya.

4) Efek suara. Efek suara dalam film diistilahkan dengan noise. Semua suara tambahan selain suara dialog, serta musik disebut efek suara. Fungsi utamanya adalah sebagai pengisi suara latar. Seperti: kalimat ayat suci yang dilantunkan oleh para santri yang menggambarkan suasana di pesantren.

5) Monolog interior. Suara pikiran (batin) dari pelaku cerita. Suara pikiran bentuknya dapat bervariasi sesuai dengan tuntutan cerita.
6) Image. Kostum dapat menjadi image bagi pelakuu cerita. Tokoh perempuan menggunakan jilbab, busana muslimah, sedangkan para santri di pesantren menggunakan kopiah, baju koko putih, dan sarung.

7) Acting. Penampilan pemain dalam dalam film secara umum dapat dibagi menjadi dua, yakni visual dan audio. Secara visual menyangkut aspek fisik, gesture, ekspresi, serta gaya bicara yang sama dengan seseorang dalam kenyataan seharihari. Secara audio bahasa bicara tidak lepas dari dialek. Dialek mempengaruhi keberhasilan sebuah cerita film karena mampu meyakinkan penonton bahwa cerita tersebut sungguh-sungguh terjadi di suatu wilayah atau mampu menunjukkan dari mana seorang karakter berasal. Misalnya kata sopo jennengmu artinya siap namamu dalam bahasa Jawa berarti orang tersebut dari jawa atau ceritanya berlokasi di Jawa.

8) Editing discontinue. Teknik kilas balik dan kilas depan yang menunjukkan terjadinya lompatan waktu pada situasi tertentu dari detik, menit, jam, hari, tahun, dan seterusnya. Pada film ini menggunakan teknik kilas balik yang memungkinkan seorang tokoh mengingat kejadian masa lampau.

\section{b. Struktur penanda film "Dalam Mihrab Cinta"}

Struktur penada film Dalam Mihrab Cinta adalah sebagai berikut.

a. Busana yang digunakan para pemain pria memakai kopiah, baju kokoh, 
menggunakan selendang di pundak, dan wanita memakai jilbab, serta berbusana muslimah. Umumnya para pemain memakai baju batik.

b. Mengucap kalimat Insya Allah, astagfirullah, Alhamdulillah, subhanallah, yang disesuaikan dengan cerita atau dialog yang dialami para pemain.

c. Saat berkomunikasi menggunakan dialek jawa seperti yo wes toh (ya sudah), hati-hati ndo' (hati-hati nak), dan sebagainya.

d. Menggunakan peribahasa Jawa dalam menanggapi suatu permasalahan. Seperti "becik ketitik olo ketoro" artinya orang baik pada akhirnya akan tampak kebaikannya dan yang salah pada akhirnya akan ketahuan juga kesalahannya.

e. Akting para pemain mewakilkan watak dari tiap tokoh di film. Seperti tokoh seorang bapak yang memiliki sifat keras dan tegas digambarkan dengan wajah yang serius, intonasi bicara yang jelas dan singkat, dengan nada keras yang menandakan sedang marah.

\section{c. Struktur petanda film "Dalam Mihrab Cinta"}

a. Pria yang berpakaian rapi, memakai kopiah, baju koko dapat dimaknai dirinya adalah seorang ustaz.

b. Wanita memakai busana muslimah, dapat dimaknai sebagai wanita salihah.

c. Pria dan wanita memakai baju batik, dapat dimaknai dengan kota mereka (Jawa pada umumnya).

d. Mengucapkan kalimat Insya Allah, ketika melakukan perjanjian, berharap rida atau meminta sesuatu pada Allah Swt. e. Berkomunikasi menggunakan dialek Jawa, seperti monggo (silahkan), hatihati $n d o^{\prime}$ (hati-hati nak), dan sebagainya.

\section{d. Struktur referent film "Dalam Mihrab Cinta"}

a. Memakai busana muslim dan muslimah, menyimbolkan nilai-nilai religius. Film yang bergenre religi tentu akan disesuaikan dengan busana yang digunakan oleh para pemain yang berfungsi sebagai mimage untuk mendukung unsurunsur film lainnya

b. Mengucapkan kalimat Insya Allah, menyimbolkan nilai religius. Kalimat ini lazim digunakan umat muslim ketika melakukan perjanjian, berharap rida atau meminta sesuatu pada Allah Swt.

c. Baju batik yang terlihat pada film ini memiliki nilai sosial budaya Jawa atau untuk mengapresiasikan kecintaannya terhadap budaya Indonesia.

d. Budaya Jawa selain identik dengan batik juga khas dengan dialek kejawenannya. Dialog-dialog yang digunakan menyimbolkan nilai-nilai sosial budaya.

Film "Dalam Mihrab Cinta" dikemas ringan dengan pendekatan religi dan sosial budaya masyarakat tertentu. Menurut Habbiburrahman cerita ini terinspirasi dari kejadian sehari-hari yang bisa dialami oleh siapa saja, dan menjadi daya tarik tersendiri, memperkenalkan suasana pesantren serta Kota Batik Pekalongan menggunkan simbol-simbol yang dapat diidentifikasi melalui busana yang digunakan, dialek, dialog, lokasi tempat di mana kisah ini terjadi.

Nilai-nilai religius dikonstruksikan dengan busana muslim dan muslimah yang digunakan para aktris dan aktor untuk membentuk image agamis. Menggunakan baju koko ketika hendak sholat di masjid, menggunakan kopiah ketika salat, memakai jilbab, memanjatkan doa, 
mengucap kalimat Insya Allah, Astagfirullah, Alhamdulillah, Subhanallah yang disesuaikan dengan alur cerita atau dialog yang dialami oleh para pemain, kubah masjid yang selalu hadir dalam scene tertentu merupakan bentuk simbol religius yang ingin ditampilkan oleh Habiburrahman dalam filmnya. Dari segi akting para pemain juga menunjukkan simbol religius dengan salat, mengajar mengaji adalah satu di antaranya.

Budaya Jawa mendominasi dalam film ini. Pengkonstruksian simbol-simbol sosial budaya masyarakat Jawa ditampilkan Habiburrahman dalam pakaian batik, butik batik milik salah satu tokoh, serta dialek dan peribahasa. Dialek tiap suku memiliki ciri khasnya masing-masing khususnya Jawa. Dikenal dengan medoknya, yaitu satu kata dalam pengucapannya agak ditekan dan terdengar doubel. Peribahasa juga memiliki makna tersendiri bagi masyarakat Jawa. Menampilkan sudut-sudut keindahan Kota Jawa, aktivitas keseharian masyarakat lokal juga menjadi salah satu cara mengkonstruksi nilai-nilai tersebut.

Film "Dalam Mihrab Cinta" menampilkan nuansa cinta yang berbeda. Film ini menceritakan seorang pria yang meninggalkan keluarganya bukan karena kebenciannya namun karena ketiadaan kepercayaan kepadanya. Menggambarkan sosok seorang pria yang difitnah di pesantren terjerumus ke dunia hitam karena desakan ekonomi. Namun atas izin Allah dan kesungguhan seorang hamba ingin merubah hidupnya, maka Allah membukakan jalan rezeki yang halal baginya. Nuansa cinta lainnya, yaitu perasaan suka antara pria dan wanita juga tidak lepas dari unsur-unsur agama. Di film ini, tampak kisah percintaan hadir menjelang akhir cerita. Terlihat pada gesture kedua tokoh perempuan, yaitu Zizi dan Syilvie jika ditanya mengenai perasaannya terhadap Syamsul jawabannya dengan tersenyum dan menatap ke bawah. Dalam Islam pun mengungkapkan "diamnya seorang wanita adalah jawabannya". Secara halus Habiburrahman memberikan simbol religi pada film ini.

Kalimat-kalimat di atas adalah sebagian contoh gambar-gambar dan dialog yang mengandung makna religi dan sosial budaya yang terdapat pada film "Dalam Mihrab Cinta". Sebagian contoh gambar-gambar dan dialog yang mengandung makna religi dan sosial budaya yang terdapat pada film "Dalam Mihrab Cinta" di antaranya adalah pola struktur naratif terbagi atas tiga tahapan. Pertama, permulaan atau pendahuluan adalah titik paling kritis dalam sebuah cerita film karena di sinilah segalanya bermula. Pelaku utama dan pendukung: pihak protagonis dan antagonis..$^{22} \mathrm{Kedua}$, tahap pertengahan, pada tahap ini alur cerita mulai berubah arah, aksi yang dilakukan karakter utama dan pendukung memicu konflik. Tempo cerita pada tahap ini semakin meningkat hingga klimaks cerita. Seringkali tokoh utama mengalami titik terendah (putus asa) baik dari segi fisik dan mental. Ketiga, tahap penutup, adalah klimaks cerita, yakni puncak dari konflik, setelah konflik berakhir maka tercapailah penyelesaian masalah, kesimpulan cerita, atau resolusi. Tokoh utama berhasil mencapai tujuannya dan bisa pula tidak.

\section{Makna Religi dan Sosial Budaya Pada Film "Dalam Mihrab Cinta"}

Makna religi dan sosial budaya pada film "Dalam Mihrab Cinta" diuraikan sebagai berikut.

a. Makna Religi

Makna religi pada film "Dalam Mihrab Cinta" ditandai dengan konstruksi visual lokasi pesantren, dengan aktivitas santri dan kiai. Dari segi bahasa diartikulasikan kedalam ucapan doa, azan, dan praktik 22 Himawan Pratista., Memahami Film (Yogyakarta : Homerian Pustaka, 2008), h. 44 
peribadatan (salat), dari segi busana menampilkan para aktris dan aktor menggunakan baju koko, kopiah, busana muslim di antaranya baju gamis.

Jika judul film "Dalam Mihrab Cinta" diartikan secara terpisah adalah "Mihrab" artinya ruang kecil di masjid, tempat imam berdiri waktu salat berjamaah. "Cinta" adalah suatu ungkapan rasa ketertarikan pada sesuatu tertentu. Namun makna yang terkandung di film "Dalam Mihrab Cinta" adalah suatu bentuk komunikasi transendental. Di mana seorang hamba memiliki tempat (mihrab) masing-masing untuk mencurahkan cinta kepada-Nya dalam wujud doa, memohon ampunan, dan lain sebagainya.

Dalam film ini Habiburrahman ElShirazy menampilkan situasi saat tokoh utama menjadi guru mengaji (mengajarkan al-Quran). Mengikuti petunjuk al-Quran dan mengamalkan al-Quran adalah jaminan kebahagiaan pribadi dan masyarakat, kebahagiaan dunia dan akhirat, karena pembuat petunjuk itu adalah Pencipta dan Mahatahu tentang ciptaan..$^{23} \mathrm{Al}$-Quran itu Kalamullah, maka siapa pun yang berkecimpung dengan Kalamullah bisa dipastikan akan mendapatkan cipratan dari keberkahan dan kebaikannya. Orang yang bersahabat dengan al-Quran akan mendapatkan predikat yang baik di mata Allah dan di mata manusia. ${ }^{24}$

b. Makna Sosial Budaya

Makna sosial budaya yang terkandung dalam film ini ditandai dengan budaya Jawa sangat kental seperti dialek, istilah-istilah

Faizah Ali Sybromalisi, Tafsir Akidah (Ciputat; UIN Jakarta Press, 2016), h. 159

24 Dr. K.H. Ahsin Sakho Muhammad, Keberkahan Al-Qur'an Memahami Tema-Tema Penting Kehidupan Dalam Terang Kitab Suci (PT. Qaf Media Kreativa, 2017), h. 19
Jawa, peribahasa, pakaian, bangunan rumah (seperti atap keraton), budaya lokal dan budaya Tiong Hoa berkembang dan hidup rukun. Dalam film ini menampilkan sisi lain di pulau Jawa bahwa gerombolan pencopet cukup besar dan kuat.

\section{Kesimpulan}

Keberadaan jenis-jenis film yang beragam, memunculkan berbagai pendapat dari praktisi media, masyarakat, dan kalangan akademisi yang concern di bidang analisis teks media. Secara teknis, proporsi dalam pembuatan film yang logis dan rasional, menurut Kristanto dalam mengulas film terdapat hal-hal yang harus diperhatikan di antaranya struktur kisahnya harus logis, memenuhi hukum sebabakibat, dan dengan sendirinya karakter tokohtokohnya juga harus berkembang sesuai dengan jalur kisah dan sebab-akibat tadi. Kedua, fotografi harus mampu menciptakan kembali realitas yang ada di depannya. ${ }^{25}$

Dakwah di zaman modern ini dapat dilakukan dengan memposisikan dakwah sebagai ilmu yang dapat dikembangkan dan dievaluasi keberadaannya. Ilmu dan praktik dakwah yang ada sekarang ini sudah saatnya dikembangkan menjadi ilmu komuniaksi Islam yang lebih compatible dengan perkembangan masyarakat dan ilmu pengetahuan di era modern ini. Kemampuan dai dalam menciptakan dan memanfaatkan teknologi informasi sebagai media dakwah perlu terus-menerus diupayakan agar dakwah betul-betul dapat dirasakan manfaatnya oleh masyarakat. Prinsip "khair al-nas anfa'uhum li nas" dapat dijadikan landasan oleh para dai dalam menggerakkan kegiatan dakwah di masyarakat.

25 Rumah Film; “Tentang Mengulas Film," Situs Resmi Rumah Film. http://www.old.rumah film.org/artikel_film.htm/ (24 November 2010). 
Film "Dalam Mihrab Cinta” karya Habiburrahman merupakan salah satu alternatif dakwah Islam melalui media Film yang diharapkan dapat memberikan manfaat tontonan yang baik, tidak hanya menghibur "to entertaiment" tetapi juga memberikan informasi dan pendidikan "to inform and to educate". Hal ini untuk memicu motivasi para sineas-produser/movie maker menyebarkan dakwah Islam sesuai dengan kreativitas masing-masing dengan berpatokan pada nilai-nilai ke-Islam-an.

Problematika kehidupan sehari-hari yang direpresentasikan melalui film "Dalam Mihrab Cinta" ini mengajarkan penonton (madu) agar memiliki prinsip hidup yang kuat, tidak mudah terjerumus ke dalam lubang hitam akibat himpitan ekonomi. Seorang manusia jika ingin merubah hidupnya haruslah dimulai dari dirinya sendiri, dengan bertaubat dan bermunajat kepada Sang Khalik. Mendekatkan diri dengan al-Quran, bergaul dengan lingkungan yang baik, maka Allah Swt. akan menunjukkan kuasa-Nya dengan menunjukkan cahaya kepada hambaNya.

Harapan agar banyaknya karya dalam bentuk film bernuansa religi dengan muatan pesan-pesan moral bisa lebih banyak digeluti oleh sineas-sineas. Sehingga dakwah Islam melalui media film dapat menjadi media dakwah yang potensial di masa mendatang.

\section{DAFTAR PUSTAKA}

Alang, Sattu, Muh. Anwar, dan Hakkar Jaya, Pengantar ilmu Komunikasi, Makassar: Alauddin Press, 2007.

Bahri, Ghazali M., Dakwah Komunikatif "Membangun Kerangka Dasar Ilmu Komunikasi Dakwah', Jakarta; CV Pedoman Ilmu Jaya, 1997.
Bisri WD, H. Hasan, Ilmu Dakwah, Surabaya: Biro Penerbitan dan Pengembangan Ilmiah, 1998.

Departemen Agama RI, Al-Qur'an dan Terjemahannya, Semarang: CV. Toha Putera, 1989.

Ensiklopedi Indonesia, Jakarta; Ichtiar Baru, 1991.

Ilahi, Wahyu, Komunikasi Dakwah, Bandung: Remaja Rosdakarya, 2010.

Kusnawan, Aep, Ilmu Dakwah, Bandung; Pustaka Bani Quraisy.

Muhammad, K.H. Ahsin Sakho, Keberkahan Al-

Quran Memahami Tema-Tema Penting Kehidupan Dalam Terang Kitab Suci, PT. Qaf Media Kreativa, 2017.

Nurwahid, H.M. Hidayat, M.A, Pengantar Sejarah Dakwah, Jakarta: Kencana, 2015.

Pratista, Himawan., Memahami Film, Yogyakarta:

Homerian Pustaka, 2008

Sobur, Alex., Semiotika Komunikasi, Cet.3;

Bandung; Remaja Rosdakarya, 2006

Subandy, Idi., Budaya Popular Sebagai

Komunikasi, Cet.1; Jogiakarta; Jalasutra, 2007

Suhadang, Kustadi., Ilmu Dakwah Perspektif Komunikasi, Bandung; Rosda, 2013

Sybromalisi, Faizah Ali., Tafsir Akidah , Ciputat;

UIN Jakarta Press, 2016

\section{Sumber lain}

Habiburrahman El Shirazy., "Habiburrahman El Shirazy Ustadz 'Luar-Dalam' di KCB, Khalifah, (Edisi 26 September 2010).

Kumpulan khutbah.blogspot.com, (Diakses 1 November 2017)

Rumah Film; "Tentang Mengulas Film," Situs Resmi Rumah Film. http://www.old.rumah film.org/artikel_film.htm/ (Diakses 24 November 2017). 
JURNAL AQLAM -- Journal of Islam and Plurality-- Volume 2, Nomor 2, Desember 2017 